\title{
Inhibition of the cellulolytic activity of Neocallimastix frontalis by Ruminococcus flavefaciens
}

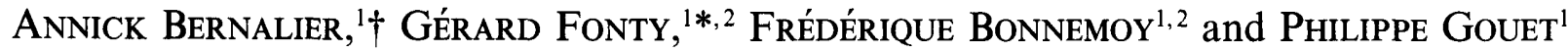 \\ ${ }^{1}$ Laboratoire de Microbiologie, INRA, Centre de Recherches de Clermont-Ferrand-Theix, \\ 63122 Saint-Genès-Champanelle, France \\ ${ }^{2}$ Laboratoire de Biologie Comparée des Protistes, CNRS, URA 0138, Université Blaise Pascal, \\ 63177 Aubière Cédex, France
}

(Received 1 June 1992; revised 12 November 1992; accepted 25 November 1992)

\begin{abstract}
A study was made of the antagonistic effect of Ruminococcus flavefaciens on the cellulolytic activity of Neocallimastix frontalis. An extracellular factor inhibiting the cellulolytic activity of the fungus was detected in the bacterial supernatant. The antagonistic factor, which precipitated with ammonium sulphate at $40 \%$ saturation, was temperature-sensitive and was destroyed at temperatures above $60^{\circ} \mathrm{C}$. After separation by anion-exchange chromatography, sequential precipitation, dialysis and SDS-PAGE, two protein species of 100 and $24 \mathrm{kDa}$ were identified as being involved in this antagonistic effect. It is not known whether the proteins are two subunits of a single protein or represent two different proteins. The inhibitory factor, which is not a bacterial cellulase, did not affect fungal growth, but it inhibited the activity of the fungal cellulases.
\end{abstract}

\section{Introduction}

Many relationships are known to exist between microorganisms in the rumen, and various workers have shown that the anaerobic fungi Neocallimastix frontalis, Piromonas communis and Sphaeromonas communis interact with hydrogen-utilizing bacteria (Bauchop \& Mountfort, 1981; Mountfort et al., 1982; Fonty et al., 1988; Joblin et al., 1990; Marvin-Sikkema et al., 1990; Joblin \& Williams, 1991; Bernalier et al., 1992). In the presence of methanogens, anaerobic fungi are more effective in degrading cellulose and their metabolism is shifted towards the production of acetate, thereby reducing that of lactate and ethanol. This phenomenon probably results from a transfer of hydrogen between the fungi and the bacteria (Wolin \& Miller, 1988). In a more recent study of the interactions between anaerobic fungi and rumen cellulolytic bacteria, Ruminococcus flavefaciens was observed to inhibit the ability of NeO-

\footnotetext{
*Author for correspondence. Tel. 73624245 ; fax 73624450 .
}

†Present address: Laboratoire de Nutrition et de Sécurité Alimentaire, INRA, 78350 Jouy en Josas, France.

Abbreviations: CMC, carboxymethylcellulose; DM, dry matter; HEC, hydroxyethylcellulose. callimastix frontalis to hydrolyse cellulose (Bernalier et al., 1988, 1992). The amount of cellulose degraded in cocultures of these two micro-organisms was considerably less than in monocultures of the fungus. The aim of the present study was to determine the basis of the inhibitory effect of $R$. flavefaciens on fungal cellulolysis.

\section{Methods}

Organisms and culture conditions. Neocallimastix frontalis $\mathrm{MCH} 3$, which is characterized by a monocentric thallus and polyflagellated zoospores (Orpin, 1975), was isolated in our laboratory from sheep rumen contents, and Ruminococcus flavefaciens 007 was kindly provided by Dr C. S. Stewart (Rowett Research Institute, Aberdeen, UK). Fungal and bacterial cultures were prepared and grown under strict anaerobiosis according to the methods of Hungate (1969). The basal medium, as described by Lowe et al. (1985) and modified by Gay et al. (1989), contained cellulose or cellobiose $(0 \cdot 2 \%, \mathrm{w} / \mathrm{v})$ as the sole carbon source. For the preparation of cellulose medium, pieces of Whatman no. 1 filter paper $(100 \mathrm{mg})$ were placed in each tube before the addition of the pre-reduced basal medium $(10 \mathrm{ml}$ per tube). The media were dispensed under $\mathrm{O}_{2}$-free $\mathrm{CO}_{2}$ in $10 \mathrm{ml}$ volumes into $\mathrm{CO}_{2}$ filled $16 \mathrm{ml}$ screw-cap Hungate tubes (Bellco Clan). The fungal inoculum consisted of a $1 \mathrm{ml}$ sample of a $48 \mathrm{~h}$ culture grown on cellobiose medium, and the bacterial inoculum consisted of $0.5 \mathrm{ml}$ aliquots of a $20 \mathrm{~h}$ culture grown on the same medium. All incubations were carried out at $39^{\circ} \mathrm{C}$ and all experiments were performed in triplicate. Cellulose degradation in experimental cultures is expressed as a percentage (mean $\pm \mathrm{SD}$ ) of that in control cultures of $N$. frontalis and $R$. flavefaciens. 
Dry matter $(D M)$ disappearance. At the end of the period of incubation, the cultures were centrifuged at $1000 \mathrm{~g}$ for $10 \mathrm{~min}$. The residual cellulose pellets were treated with $1 \mathrm{M}-\mathrm{NaOH}$ at $100{ }^{\circ} \mathrm{C}$ to remove bacterial and fungal material, then rinsed twice in distilled water and dried to a constant weight at $80^{\circ} \mathrm{C}$.

Inhibitory factor produced by $R$. flavefaciens. After $4 \mathrm{~d}$ of incubation $\left(t_{4}\right)$, the fungal and the bacterial monocultures were centrifuged at $1000 \mathrm{~g}$ for $10 \mathrm{~min}$ in their culture tubes to harvest non-degraded filter paper and micro-organisms attached to cellulose fibres. The bacterial supernatant was centrifuged again at $3000 \mathrm{~g}$ for $10 \mathrm{~min}$ to remove the bacterial cells. The fungal and bacterial supernatants were then sterilized by passage through a $0.2 \mu \mathrm{m}$ mesh Millipore filter in an anaerobic glove box. The fungal supernatant was added to the nondegraded bacterial cellulose pellet and the bacterial supernatant was added to the non-degraded fungal cellulose pellet. These cultures were then incubated for $4 \mathrm{~d}\left(t_{8}\right)$ and the dry matter (DM) disappearance of cellulose and the fungal and bacterial biomasses were determined. The fungal and bacterial biomasses were assayed by measuring the protein contents according to Bradford (1976).

A series of control cultures was made by suspending fungal and bacterial pellets with their own supernatants, i.e. the cultures were reconstituted. In addition, for all experiments, $N$. frontalis and $R$. flavefaciens were cultured on filter paper as controls and incubated for $8 \mathrm{~d}$.

Influence of various treatments of the bacterial supernatant on the interaction between $N$. frontalis and $R$. flavefaciens. To study the effect of the age of the bacterial supernatant on the fungal cellulose degradation, the supernatant of $R$. flavefaciens was taken after 2, 4 or $6 \mathrm{~d}$ of culture and added to a 4-d-old fungal cellulose pellet. The cultures were then incubated for $4 \mathrm{~d}$. To study the effect of the volume of the bacterial supernatant exchanged, $1,5,8$ or $10 \mathrm{ml}$ of this supernatant, representing $10,50,80$ and $100 \%$, respectively, of the total supernatant, were exchanged after $4 \mathrm{~d}$ of incubation. To study the effect of temperature, bacterial supernatants collected from the 4-d-old cultures of $R$. flavefaciens were heated for $15 \mathrm{~min}$ at $50,60,80$ and $100{ }^{\circ} \mathrm{C}$ and then mixed with fungal cellulose pellets and incubated for $4 \mathrm{~d}$. In all these studies, only the DM disappearance of filter paper was measured at the end of the period of incubation $\left(t_{8}\right)$.

Adsorption of cellulases. To remove the fungal and bacterial cellulases, the supernatants were treated with a mixture of equal amounts of different celluloses: Sigmacell 50 and 100, Avicel, cellulose fibre, and ground filter paper (for the effectiveness of this treatment, see Results). One hundred milligrams of this cellulose mixture was added to each of the supernatants from 4-d-old cultures and incubated for 15 min with shaking. After incubation, the tubes were centrifuged at $700 \mathrm{~g}$ for $10 \mathrm{~min}$ to precipitate the cellulose. They were centrifuged twice more, after which the endoglucanase activity of the supernatants was measured by viscosimetry with hydroxyethylcellulose (HEC) as substrate (Gaudet, 1983). The treated supernatants of the fungal and bacterial cultures were exchanged as described above. After $4 \mathrm{~d}$ of incubation $\left(t_{8}\right)$, the DM disappearance of the filter paper was determined.

Determination of the biochemical nature of the bacterial factor. Proteins in the supernatants of bacterial cultures were precipitated with ammonium sulphate at $\mathbf{4 0}$ or $60 \%$ saturation. After centrifugation at $7000 \mathrm{~g}$ for $15 \mathrm{~min}$, the bacterial proteins were suspended in $0.5 \mathrm{ml}$ $0.02 \mathrm{M}$-Tris $/ \mathrm{HCl} \mathrm{pH} \mathrm{8.0} \mathrm{(buffer} \mathrm{T}$ ) and their concentrations were assayed spectrophotometrically using bicinchoninic acid (BCA) reagent (Pierce-Amersham). The proteins precipitated by ammonium sulphate were then added to a 4-d-old fungal culture. The proteins from the culture supernatants in which the cellulases had been partially absorbed on celluloses were treated in the same manner. Proteins from an uninoculated medium were also collected and added to the fungal cultures. DM measurements were made $4 \mathrm{~d}\left(t_{8}\right)$ after the addition of the bacterial proteins to the fungal cultures. A control culture was made by adding to a 4-d-old fungal culture the same concentration of ammonium sulphate as that used in the assay cultures.

Mode of action of the bacterial factor. To study the effect of the factor on the growth of $N$. frontalis, the fungus was cultured on medium containing $0.2 \%$ glucose. The bacterial proteins collected from a filter paper culture supernatant after precipitation with $40 \%$ saturated ammonium sulphate solution were added to $17 \mathrm{~h}$ fungal cultures. After $72 \mathrm{~h}$ incubation, the fungal biomass was determined by protein assay according to the method of Bradford (1976) as described above. Cultures of $N$. frontalis 17 and $72 \mathrm{~h}$ old were used as controls. To study the effect of the bacterial factor on the fungal cellulases, the fungal proteins were precipitated from culture supernatants with $40 \%$ saturated ammonium sulphate solution and concentrated by ultrafiltration-centrifugation (Centricon 10 microconcentrators, cut-off $10 \mathrm{kDa}$, Amicon). Electrophoresis of these proteins was performed with a non-denaturing polyacrylamide gel containing $1 \%(\mathrm{w} / \mathrm{v})$ carboxymethylcellulose (CMC) (Schwartz et al., 1987). After migration, the gel was incubated overnight at $39^{\circ} \mathrm{C}$ in $50 \mathrm{~mm}-\mathrm{K}_{2} \mathrm{HPO}_{4}$ buffer (pH 7.0) in the absence or presence of bacterial supernatant. The gel was then stained for $30 \mathrm{~min}$ in a $0.1 \%$ solution of Congo Red and rinsed with $1 \mathrm{M}-\mathrm{NaCl}$.

Synthesis and secretion of the bacterial factor. The inhibitory effect of a supernatant from $R$. flavefaciens culture obtained from basal medium containing $0.2 \%$ cellobiose was measured. The bacterial cultures in exponential or stationary phase were centrifuged at $3000 \mathrm{~g}$ for $15 \mathrm{~min}$, and the supernatants recovered and filtered through $0.2 \mu \mathrm{m}$ Millipore filters. The supernatants were mixed with 4-d-old fungal pellets grown on filter paper medium. These cultures were incubated for $4 \mathrm{~d}$ and the DM disappearance of cellulose was determined.

Partial purification of the bacterial factor. Filtered supernatants from bacterial cultures were subjected to chromatographic analysis in an anion-exchange column (Millipore, DEAE Memsep 1000) equilibrated with buffer $T$. The non-retained fraction was collected and the proteins retained in the column were eluted with different concentrations of $\mathrm{NaCl}(0 \cdot 25,0 \cdot 5,0.75$ or $1.0 \mathrm{M})$ in buffer $\mathrm{T}$. The elution of the proteins was followed at $280 \mathrm{~nm}$. The protein fractions recovered were precipitated with ammonium sulphate at $60 \%$ saturation and then redissolved in buffer $T$. The effectiveness of each fraction in inhibiting fungal cellulolysis was determined by measuring the amount of residual substrate $4 \mathrm{~d}$ after addition of the protein pool to a 4-d-old fungal culture grown on basal medium. Subsequently, the fractions were analysed by SDS-PAGE in a $12 \%(\mathrm{w} / \mathrm{v})$ polyacrylamide gel according to Laemmli (1970). After migration, the electrophoresis gels were stained with silver (Oakley, 1980).

Medium fractionation by precipitation. After adsorption of the cellulases onto celluloses the supernatants from 4-d-old $R$. flavefaciens cultures were treated sequentially with ammonium sulphate at 20,40 and $70 \%$ saturation. The precipitated proteins were added to buffer $\mathrm{T}$, concentrated by ultrafiltration and analysed by electrophoresis (SDSPAGE). The inhibitory activity of each protein fraction against fungal cellulolysis was also determined by adding the proteins to 4-d-old fungal cultures and measuring the DM disappearance of cellulose after $4 \mathrm{~d}$ incubation $\left(t_{8}\right)$.

Medium fractionation by dialysis. The supernatants of $R$. favefaciens were treated with the cellulose mixture and dialysed on an ultrafiltration membrane having a $50 \mathrm{kDa}$ cut-off against $20 \mathrm{~mm}-\mathrm{KH}_{2} \mathrm{PO}_{4}(\mathrm{pH} 7 \cdot 0)$. The proteins retained in the supernatant were then precipitated with ammonium sulphate at $60 \%$ saturation and concentrated by ultrafiltration. The protein fraction collected was first analysed by SDSPAGE and then added to a 4-d-old fungal culture to study its effect on fungal cellulolysis. 


\section{Results}

Inhibitory factor produced by $R$. flavefaciens

When added to $N$. frontalis, the $3000 \mathrm{~g}$ supernatant prepared from an $R$. flavefaciens culture inhibited the extent of cellulose degradation (Fig. 1). In contrast, the fungal supernatant stimulated bacterial cellulolysis : $30 \%$ more cellulose was degraded by bacterial cultures to which fungal supernatants had been added (Fig. 1). After $8 \mathrm{~d}$ incubation, the biomasses of the fungal and bacterial cultures whose supernatants had been exchanged were comparable to those of their respective controls (Table 1). This shows that the exchange of supernatants did not affect the growth of either micro-organism. To determine whether the increase in bacterial cellulolysis was due to the presence of fungal cellulases in the exchange supernatant, the latter was incubated at $39^{\circ} \mathrm{C}$ in the presence of a mixture of celluloses. The endoglucanase activity of the supernatants was then measured by viscosimetry and was found to have only a quarter of the activity of the supernatants of unadsorbed controls $(9 \pm 2 \%$ of decrease in the viscosity of an HEC solution versus $36 \pm 2 \%$ ), showing that the cellulose mixture

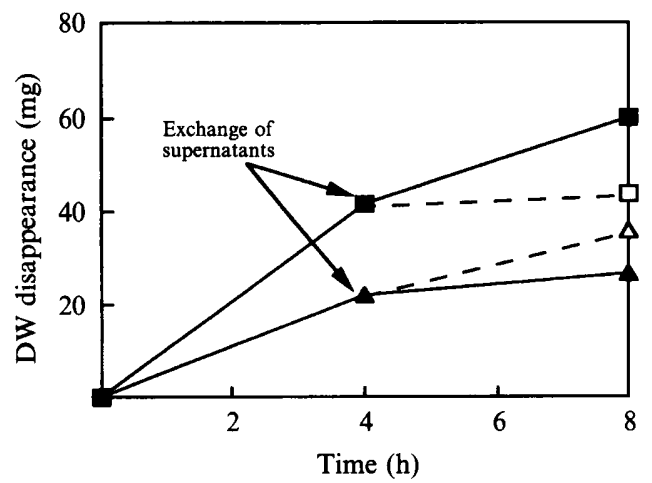

Fig. 1. Kinetics of filter paper degradation in cultures of $N$. frontalis $(\square, \square)$ and $R$. flavefaciens $(\boldsymbol{\Delta}, \triangle)$. Filled symbols, control cultures; open symbols, after the supernatant exchange. Each experimental value represents the mean of three assays. The SD values were $<5 \%$ of the mean and are not indicated on the figure.

Table 1. Growth of $N$. frontalis and R. flavefaciens in control cultures and in cultures whose supernatants were exchanged after $4 d$ of incubation

\begin{tabular}{|c|c|c|c|c|}
\hline \multirow{3}{*}{$\begin{array}{l}\text { Culture } \\
\text { age } \\
\text { (d) }\end{array}$} & \multicolumn{4}{|c|}{ Biomass $\left(\mu \mathrm{g} \text { protein } \mathrm{ml}^{-1}\right)^{*}$} \\
\hline & \multicolumn{2}{|c|}{ N. frontalis } & \multicolumn{2}{|c|}{ R. flavefaciens } \\
\hline & Control & $\begin{array}{c}\text { After } \\
\text { exchange }\end{array}$ & Control & $\begin{array}{c}\text { After } \\
\text { exchange }\end{array}$ \\
\hline 4 & $78 \cdot 8 \pm 9 \cdot 7$ & - & $100 \cdot 6 \pm 1 \cdot 8$ & - \\
\hline 8 & $91 \cdot 6 \pm 1 \cdot 8$ & $94 \cdot 6 \pm 7 \cdot 6$ & $108.7 \pm 9.9$ & $108 \cdot 3 \pm 9 \cdot 4$ \\
\hline
\end{tabular}

*Each value represents mean $\pm \mathrm{SD}(n=3)$. treatment resulted in good adsorption of cellulases. When treated with cellulose, the fungal supernatant lost much of its effect on cellulose degradation in the bacterial culture (an increase of $2 \pm 1.9 \%$ compared with $24.7 \pm 1.8 \%$ with untreated supernatant). Hence, the removal of fungal cellulases by adsorption depresses the cellulolytic activity of the supernatant.

\section{Influence of various treatments of the bacterial supernatant on the interaction between $N$. frontalis and R. flavefaciens}

The inhibitory effect of the bacterial supernatant on the cellulolytic activity of the fungus was the same for exchanges of supernatants made after 2,4 or $6 \mathrm{~d}$ of culture. The bacterium inhibited the cellulolysis of $N$. frontalis even when only a small volume of supernatant was transferred: $1 \mathrm{ml}$ of supernatant was sufficient to achieve maximum inhibition of fungal cellulolysis (Table 2). The extent of cellulose degradation increased slightly with the increase in the volume of the bacterial supernatant. The antagonistic effect of the bacterial supernatant on the cellulolytic activity of the fungus was only slightly affected after it had been heated at $50^{\circ} \mathrm{C}$, but was completely destroyed at 60,80 and $100^{\circ} \mathrm{C}$. In controls, the cellulolytic ability of $N$. frontalis was not affected after resuspension in its own heated supernatant.

After successive incubations of the bacterial supernatants with mixtures of celluloses, most of the extracellular cellulases produced by $R$. flavefaciens were removed from the supernatant, e.g. the endoglucanase activity of these supernatants was only a third of that of non-adsorbed controls $(9 \cdot 3 \pm 1.5 \%$ decrease in the viscosity of an HEC solution versus $31.2 \pm 0.9 \%$ ). Treatment with a mixture of celluloses did not alter the effect of the bacterial supernatant on the fungal activity $(69 \cdot 7 \pm 4.4 \%$ of cellulose degraded compared with $70 \cdot 9 \pm 1 \cdot 4 \%)$.

\section{Biochemical nature of the factor}

The proteins in the bacterial supernatant reduced the amount of cellulose degraded by fungal cultures (Table 3 ). The greatest inhibitory effect of these proteins was observed when they were precipitated with ammonium sulphate at $60 \%$ saturation (Table 3). The proteins from a bacterial supernatant treated with a mixture of celluloses were also capable of decreasing fungal cellulolysis. The inhibitory activity of these proteins was slightly greater than that of both the total bacterial supernatant and the proteins separated from it (Table 3). The proteins from uninoculated culture medium did not decrease fungal cellulolysis (Table 3). Therefore the antagonistic effect on fungal cellulolysis of the proteins 
Table 2. Effect of the amount of R. flavefaciens supernatant exchanged on cellulose degradation by $N$. frontalis

The bacterial supernatant was added to the $N$. frontalis culture after $4 \mathrm{~d}$. Cellulose degradation was measured $4 \mathrm{~d}$ later.

\begin{tabular}{|c|c|}
\hline $\begin{array}{c}\text { Amount of supernatant } \\
\text { exchanged } \\
\text { (\% of final volume) }\end{array}$ & $\begin{array}{c}\text { Cellulose degraded by } \\
N . \text { frontalis } \\
(\% \text { of that degraded in } \\
\text { control })^{*}\end{array}$ \\
\hline 0 & $100 \cdot 0 \pm 0 \cdot 0$ \\
\hline 10 & $52.7 \pm 2.3$ \\
\hline 50 & $55 \cdot 5 \pm 2 \cdot 4$ \\
\hline 80 & $56 \cdot 5 \pm 2.6$ \\
\hline 100 & $62 \cdot 1 \pm 0 \cdot 9$ \\
\hline
\end{tabular}

* Each value represents the mean \pm SD $(n=3)$.

Table 3. Effect on the degradation of cellulose by $N$. frontalis of the addition of proteins precipitated from the supernatant of $R$. flavefaciens culture, proteins precipitated from the sterile culture medium, and the bacterial supernatant treated with a mixture of celluloses

Cellulose degradation was measured $4 \mathrm{~d}$ after the addition of proteins.

\begin{tabular}{lc}
\hline \hline & $\begin{array}{c}\text { Cellulose degraded by } \\
N \text {. frontalis } \\
\text { (\% of that degraded in } \\
\text { control culture) }\end{array}$ \\
\hline Addition & $72 \cdot 1 \pm 3 \cdot 7$ \\
\hline Total bacterial supernatant & \\
Bacterial supernatant proteins precipitated & \\
by & $87 \cdot 1 \pm 2 \cdot 8$ \\
$40 \%$ saturated $\left(\mathrm{NH}_{4}\right)_{2} \mathrm{SO}_{4}$ & $76 \cdot 1 \pm 4.5$ \\
$60 \%$ saturated $\left(\mathrm{NH}_{4}\right)_{2} \mathrm{SO}_{4}$ & $96 \cdot 5 \pm 1 \cdot 7$ \\
Proteins from an uninoculated medium \\
precipitated by $40 \%$ saturated $\left(\mathrm{NH}_{4}\right)_{2} \mathrm{SO}_{4}$ \\
Proteins from a bacterial supernatant \\
treated with cellulose and precipitated by \\
$40 \%$ saturated $\left(\mathrm{NH}_{4}\right)_{2} \mathrm{SO}_{4}$ \\
\hline \hline
\end{tabular}

* Each value represents the mean \pm SD $(n=3)$.

from the bacterial supernatants was not due to a component of the culture medium. In the control culture, the addition of $33 \mathrm{~mm}$-ammonium sulphate (corresponding to the concentration in a $60 \%$ saturated solution) did not reduce the cellulolytic activity of the fungus.

\section{Mode of action of the factor}

The results in Table 1 suggest that the bacterium had no antagonistic effect on fungal growth. To confirm this, $N$. frontalis was cultured on glucose medium in the absence and presence of bacterial proteins. The addition of bacterial proteins to a 20 -h-old $N$. frontalis culture did not affect its growth, since after $72 \mathrm{~h}$, the concentration

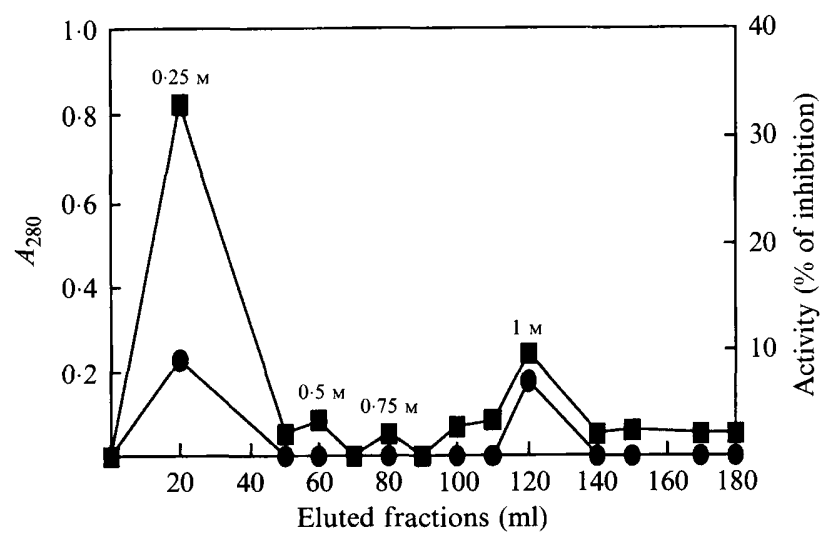

Fig. 2. DEAE-Mensep 1000 ion-exchange chromatography (DEAE) of $R$. flavefaciens culture supernatant. The proteins were eluted by stepwise addition of $\mathrm{NaCl}$ and the $A_{280}$ measured ( $\square$ ). The inhibitory activity of each protein fraction was determined by measuring the amount of cellulose (DW) degraded by $N$. frontalis after the addition of these fractions and is expressed as the percentage of degradation (mg DW disappeared) in the control fungal culture that had undergone supernatant exchange with $R$. flavefaciens $(\mathbf{O})$.

of fungal proteins found was the same in the presence and absence of the bacterial factor.

The cellulolytic activity of the fungus was examined by zymogram analysis. When no bacterial supernatant was added to the gel incubation buffer, the fungal cellulases had a high hydrolytic activity against CMC embedded in the gel (large zone of clearing on the gel). The addition of bacterial supernatant to the incubation buffer strongly inhibited the CMCase activity of $N$. frontalis (no zone of cellulolysis on the gel).

\section{Secretion of the factor by the bacterium}

The effectiveness of the inhibition of the bacterial supernatant was the same whether cellobiose or cellulose was used as the carbon source for bacterial growth. Supernatants from exponential-phase bacterial cultures grown on cellobiose had a slightly lower inhibitory activity than supernatants from stationary-phase cultures.

Partial purification of the inhibitory protein secreted by R. flavefaciens

The supernatants of $R$. flavefaciens cultures were passed through an anion-exchange column. The two protein peaks obtained by elution with $0 \cdot 25$ and $1 \mathrm{M}-\mathrm{NaCl}$ were quantitatively the highest and represented the fractions containing the inhibiting factor (Fig. 2). The two other salt concentrations eluted only a small amount of proteins and these had no effect on fungal cellulolysis (Fig. 2). The specific activity of the proteins eluted with $1 \mathrm{M}-\mathrm{NaCl}$ was greater than that of proteins eluted with 
Table 4. Effect on the cellulose degradation by $N$. frontalis of protein fractions from the supernatant of an $R$. flavefaciens culture

The fractions were obtained by elution from a DEAE column (see Methods). Cellulose degradation was measured $4 \mathrm{~d}$ after the addition of proteins.

\begin{tabular}{|c|c|c|}
\hline Treatment & $\begin{array}{l}\text { Cellulose degraded } \\
\text { by } N . \text { frontalis } \\
\text { (\% of that degraded } \\
\text { in control) }\end{array}$ & $\begin{array}{l}\text { Specific activity } \\
\text { [mg dry wt } \\
\text { cellulose degraded } \\
\text { (mg added } \\
\text { protein })^{-1} \text { ] }\end{array}$ \\
\hline \multicolumn{3}{|l|}{ Exchange of } \\
\hline Total supernatant & $72 \cdot 8 \pm 3 \cdot 2$ & $90 \cdot 6$ \\
\hline Non-retained fraction & $102 \pm 5 \cdot 1$ & ND \\
\hline \multicolumn{3}{|l|}{$\begin{array}{l}\text { Addition of proteins } \\
\text { eluted by }\end{array}$} \\
\hline $0.25 \mathrm{M}-\mathrm{NaCl}$ & $90 \cdot 8+4 \cdot 1$ & 230 \\
\hline $0.50 \mathrm{M}-\mathrm{NaCl}$ & $100 \cdot 0 \pm 1.9$ & ND \\
\hline $0.75 \mathrm{M}-\mathrm{NaCl}$ & $114 \cdot 4 \pm 3 \cdot 8$ & ND \\
\hline $1 \mathrm{M}-\mathrm{NaCl}$ & $92.9 \pm 1.7$ & $645 \cdot 5$ \\
\hline
\end{tabular}

ND, Not determined.

$0.25 \mathrm{M}-\mathrm{NaCl}$ (Table 4). Hence the activity of the antagonistic factor seemed to be greater in the second peak. The bacterial proteins recovered from the anionexchange column came from six supernatants and, since protein from a single supernatant was sufficient to produce maximum inhibitory activity, no increased inhibition was expected by using protein from six supernatants. Therefore it was possible to compare the inhibitory effects produced by culture supernatants with that of proteins eluted from the column. While the transfer of the bacterial supernatant to the fungal culture resulted in a $27 \%$ decrease in the cellulose degraded, the addition of the two protein fractions $(0.25$ and $1 \mathrm{M})$ produced a decrease of only $16 \cdot 3 \%$. It is possible that some inhibitory proteins were lost during purification, since a protein yield of $72 \%$ was obtained. However, the decreased effectiveness of the inhibitory proteins may also have been due to alterations in their activity during the different treatments.

Electrophoretic analysis of the proteins from a bacterial supernatant showed four major protein bands, corresponding to proteins with molecular masses of 100 , 65,45 and $24 \mathrm{kDa}$ (Fig. 3, lane 2). The electrophoretic pattern of the bacterial supernatant treated with a mixture of celluloses showed a sharp decrease in the number of protein bands compared to the untreated supernatant (Fig. 3, lane 3); this is explained by the cellulose treatment eliminating a large number of extracellular cellulases. However, three major protein bands $(100,65$ and $24 \mathrm{kDa})$ were not eliminated by the treatment and might therefore have been involved in the inhibitory effect of $R$. flavefaciens on the cellulolysis by the fungus. The inhibitory activity of the cellulosetreated supernatant could only have been due to the action of one or all three of the proteins. The disappearance of the $45 \mathrm{kDa}$ major protein band from the cellulose-treated supernatants suggests that this protein corresponds to one of the bacterial hydrolases. Analysis of the proteins in the non-retained fraction in the anion-exchange column showed the presence of many protein bands, including two major bands corresponding to molecular masses of 65 and $45 \mathrm{kDa}$ (Fig. 3 , lane 4). The absence of any inhibitory activity of this protein pool against $N$. frontalis (Table 4) indicates that the 65 and $45 \mathrm{kDa}$ proteins of the bacterial supernatant were not involved in the inhibitory effect. In contrast, the protein bands corresponding to molecular masses of 100 and $24 \mathrm{kDa}$, which were absent from the non-retained fraction, were found in large quantities in the protein pool eluted with $0.25 \mathrm{M}-\mathrm{NaCl}$ (Fig. 3, lane 5). Since this protein fraction, like the cellulose-treated bacterial supernatant, had inhibitory activity against the fungal cellulolysis, one of the two major protein bands, or both together, might correspond to the factor involved in the inhibition of the cellulolytic activity of $N$. frontalis.

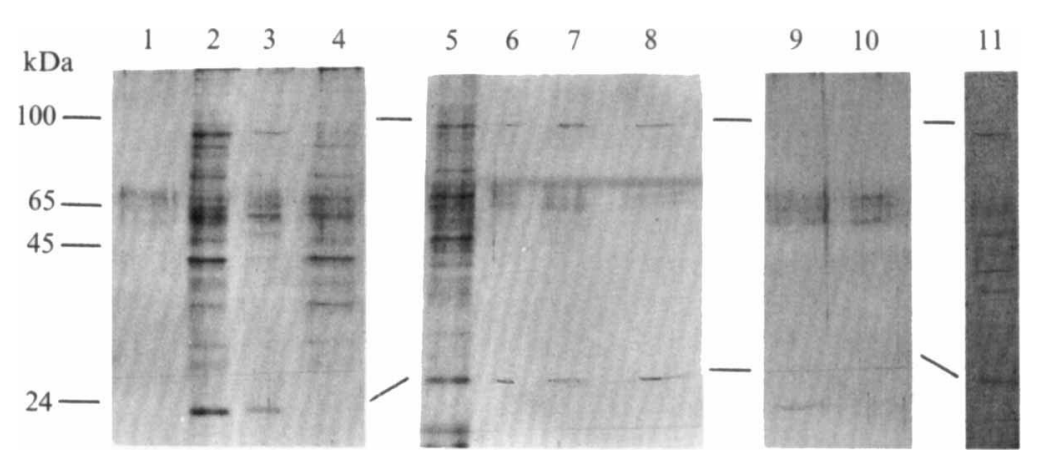

Fig. 3. SDS-PAGE analysis of protein fractions. Lanes: 1 , uninoculated medium; 2 , supernatant of $R$. flavefaciens culture on filter paper; 3 , supernatant of $R$. flavefaciens culture after treatment with a mixture of celluloses; 4 , fraction of the bacterial supernatant not retained on the ion-exchange column; 5, fractions of the bacterial supernatant eluted from the anionexchange column with $0.25 \mathrm{M}-\mathrm{NaCl} ; 6-8$, fraction of the bacterial supernatant precipitated with $\left(\mathrm{NH}_{4}\right)_{2} \mathrm{SO}_{4}$ at (6) $20 \%$, (7) $40 \%$ and (8) $70 \%$ saturation; 9-10, fraction of the bacterial supernatant eluted from the anion-exchange column with (9) $0.75 \mathrm{M}-\mathrm{NaCl}$ and (10) $0.5 \mathrm{M}-\mathrm{NaCl} ; 11$, fractions of the bacterial supernatant retained by an ultrafiltration membrane having a cut-off of $50 \mathrm{kDa}$. The sizes of the bands were determined by comparing their position with those of standard proteins. 
Table 5. Effect on the cellulose degradation by $N$. frontalis of the addition of the protein fraction of the supernatant of an $R$. flavefaciens culture, treated with a mixture of celluloses

The protein fraction was either precipitated sequentially by $\left(\mathrm{NH}_{4}\right)_{2} \mathrm{SO}_{4}$ or dialysed and then precipitated with $\left(\mathrm{NH}_{4}\right)_{2} \mathrm{SO}_{4}$. Cellulose degradation was measured $4 \mathrm{~d}$ after the addition of proteins.

\begin{tabular}{lc}
\hline \hline $\begin{array}{l}\text { Treatment of bacterial } \\
\text { supernatant added }\end{array}$ & $\begin{array}{c}\text { Cellulose degraded by } \\
N \text {. frontalis } \\
\text { (\% of that degraded in } \\
\text { control cultures) }\end{array}$ \\
\hline Cellulose-treated & $78.6 \pm 1 \cdot 8$ \\
Fractionation of proteins by & \\
sequential precipitation with & $83.2 \pm 1 \cdot 8$ \\
$20 \%$ saturated $\left(\mathrm{NH}_{4}\right)_{2} \mathrm{SO}_{4}$ & $75 \cdot 3 \pm 2 \cdot 1$ \\
$40 \%$ saturated $\left(\mathrm{NH}_{4}\right)_{2} \mathrm{SO}_{4}$ & $94.4 \pm 1 \cdot 7$ \\
$70 \%$ saturated $\left(\mathrm{NH}_{4}\right)_{2} \mathrm{SO}_{4}$ & $81 \cdot 4 \pm 8 \cdot 4$ \\
Dialysis and precipitation with & \\
$60 \%$ saturated $\left(\mathrm{NH}_{4}\right)_{2} \mathrm{SO}_{4}$ & \\
\hline \hline
\end{tabular}

* Each value represents the mean $\pm \mathrm{SD}(n=3)$.

\section{Sequential precipitation and dialysis of the bacterial supernatant}

To determine whether the expression of inhibitory activity required the presence of one or both of the 100 and $24 \mathrm{kDa}$ proteins, the proteins were separated by two different techniques: sequential ammonium sulphate precipitation, and dialysis.

The greatest inhibition of fungal cellulolysis was observed with the protein fraction precipitated at $40 \%$ ammonium sulphate saturation. The bacterial proteins precipitated at $20 \%$ ammonium sulphate saturation also had an inhibitory effect, but those precipitated at $70 \%$ saturation had only a slight inhibitory effect (Table 5). The electrophoretic profiles of the proteins precipitated at the three successive ammonium sulphate concentrations showed the presence of two major protein bands of 100 and $24 \mathrm{kDa}$ (Fig. 3, lanes 6-8). The presence of these two protein bands suggested the existence of two proteins of very different molecular masses. These bands could also correspond to two subunits of the same protein, since electrophoresis was carried out in denaturing conditions. This protein might have been precipitated by the successive concentrations of ammonium sulphate, which would explain why its inhibitory activity was observed in the three fractions.

When proteins from a cellulose-treated bacterial supernatant were dialysed with a membrane having a cut-off of $50 \mathrm{kDa}$ and then added to a 4-d-old fungal culture, there was a decrease in the cellulolytic activity of the fungus (Table 5). The factor responsible for the inhibitory effect of the bacterial supernatant was there- fore present in the protein fraction that was retained. The analysis of this fraction by electrophoresis in denaturing conditions showed a sharp decrease in the number of protein bands compared with the protein pattern obtained for a supernatant adsorbed to cellulose but not dialysed. However, the major protein bands of 100 and $24 \mathrm{kDa}$ were still present (Fig. 3, lane 11). The technique used was thus not able to separate these two protein bands, both of which may be involved in the inhibitory effect.

\section{Discussion}

This study confirms the existence of an interaction between $N$. frontalis and the cellulolytic bacterium $R$. flavefaciens in the degradation of cellulose observed previously (Bernalier et al., 1988, 1992) and demonstrates the nature of the factor involved in the inhibition of fungal cellulolysis by $R$. flavefaciens.

When the supernatant of $N$. frontalis was transferred to a culture of $R$. flavefaciens, the amount of cellulose degraded in the bacterial culture rose by $25 \%$. This increase in cellulolysis was probably due to the activity of the fungal cellulases supplied by the supernatant of $N$. frontalis. The glucose released by the cellulolytic enzymes was not used by the strain of $R$. flavefaciens 007 studied (A. Bernalier, unpublished results), which explains why there was no stimulation of the bacterial growth. In contrast, the transfer of a small volume of a supernatant of a culture of $R$. flavefaciens to a culture of $N$. frontalis inhibited the cellulolytic activity of the latter (approximately $30 \%$ less cellulose was degraded compared to untreated fungal culture). The fungal biomass was not influenced because when the bacterial supernatant was added, the fungal growth was almost at its highest.

The inhibition of fungal activity is caused by an extracellular protein released by the cellulolytic bacterium. Although the inhibitory factor was only partly characterized, we identified two proteins with molecular masses of 100 and $24 \mathrm{kDa}$ which may have been involved in the antagonistic effect. The fact that the attempts to separate these two protein bands were unsuccessful suggests that the inhibitory factor might be a protein composed of two subunits. The inhibitory activity observed in the two major protein pools recovered from the anion-exchange column (fractions eluted with 0.25 and $1 \mathrm{M}-\mathrm{NaCl}$ ) was probably due to the protein being progressively eluted as the salt concentration was increased. The weak inhibitory effect of the protein fractions may have been caused by the loss of a part of these proteins during purification or by a decrease in their activities in the course of the different treatments. However, the existence of two different protein fractions (eluted at 0.25 and $1 \mathrm{M}-\mathrm{NaCl}$ ) having antagonistic effects 
against fungal cellulolytic activity suggests that there were two distinct inhibitory proteins, able to act separately but achieving maximum activity when associated. Electrophoretic analysis of the protein pattern of the fraction eluted with $1 \mathrm{M}-\mathrm{NaCl}$ should indicate whether the inhibiting factor was the same as that in the $0.25 \mathrm{M}$ fraction. Unfortunately, the amount of protein eluted with $1 \mathrm{M}-\mathrm{NaCl}$ was insufficient both to check the inhibitory effect and to do the electrophoretic analysis. The presence of the 100 and $24 \mathrm{kDa}$ proteins in the fraction eluted with $0.25 \mathrm{M}-\mathrm{NaCl}$ is consistent with the possibility that the inhibitory protein is made up of two subunits. However, it is also possible that each of the suspected subunits comes from a different protein. If this were the case they would have molecular masses of $50 \mathrm{kDa}$ or more since they were not separated by dialysis in which a membrane with a cut-off equal to this molecular mass was used.

The cellulase activity of $N$. frontalis was greatly inhibited by the presence of the bacterial protein, as evidenced by the zymogram analyses, but fungal growth was not affected. The bacterial supernatant in the incubation buffer of the gel inhibited fungal cellulases.

The mechanism by which the bacterial protein inhibits fungal cellulases was not elucidated. The fact that the extent of the inhibition of the cellulolytic activity of $N$. frontalis was the same after adsorption of the cellulases of $R$. flavefaciens on a mixture of celluloses clearly indicates that the inhibitory bacterial protein was not a cellulase. Since only a small amount of the bacterial supernatant was required to produce a great inhibitory effect, the factor could be an enzyme that acts on the fungal cellulase complex. However, this enzyme is probably not a protease since $R$. flavefaciens is not a proteolytic species (Stewart \& Bryant, 1988). The inhibitory protein may have homologies with one of the enzymes that take part in the formation of the fungal cellulase complex and thereby prevent the formation of a functional hydrolytic complex, or it may have a closer affinity for one of the enzymes of the complex and specifically inhibit it. The action of this inhibiting factor on the cellulolysis of other cellulolytic micro-organisms (anaerobic bacteria or aerobic fungi) should be studied to determine the specificity of the protein for cellulases and to provide information on its mode of action. Little is known about the factors capable of inhibiting the cellulases of rumen anaerobic fungi and work has focused mainly on metals such as iron and mercury (Barichievich \& Calza, 1990).

Our in vitro study shows that a dominant bacterial species of the rumen is capable of decreasing the cellulolytic activity of a rumen fungus that is very effective in degrading cellulose (Hebraud \& Févre, 1988; Gordon \& Phillips, 1989; Bernalier et al., 1992).
Gnotobiotic lambs harbouring a defined cellulolytic flora (Fonty \& Gouet, 1989) could be a suitable animal model to determine if this interaction occurs in the rumen.

We thank Drs E. Forano and G. Gaudet for stimulating discussions during the experiment, Professor A. P. J. Trinci for his help in the preparation of the manuscript, and Mrs J. Gouet and Mr G. Andant for their excellent technical assistance.

\section{References}

Bauchop, T. \& MountForT, D. O. (1981). Cellulose fermentation by a rumen anaerobic fungus in both the absence and the presence of rumen methanogens. Applied and Environmental Microbiology 42, 1103-1110.

Barichievich, E. A. \& Calza, R. E. (1990). Media carbon induction of extracellular cellulase activities in Neocallimastix frontalis isolate EB188. Current Microbiology 20, 265-271.

Bernalier, A., Fonty, G. \& Gouet, PH. (1988). Dégradation et fermentation de la cellulose par Neocallimastix sp. $\mathrm{MCH} 3$ seul ou associé à quelques espèces bactériennes du rumen. Reproduction Nutrition Developpement 28 (suppl. 1), 75-76.

Bernalier, A., Fonty, G., Bonnemoy, F. \& Gouet, Ph. (1992). Degradation and fermentation of cellulose by the rumen anaerobic fungi in axenic cultures or in association with cellulolytic bacteria. Current Microbiology 25, 145-148.

BrADFORD, M. M. (1976). A rapid and sensitive method for the quantitation of microgram quantities of protein utilizing the principle of protein-dye binding. Analytical Biochemistry 72, 248-254.

FONTY, G. \& GouET, PH. (1989). Establishment of microbial populations in the rumen. Utilization of an animal model to study the role of the different cellulolytic micro-organisms, in vivo. In The Role of Protozoa and Fungi in Ruminant Digestion, pp. 39-50. Edited by J. V. Nolan, R. A. Leng \& D. I. Demeyer. Armidale: Penambul Books.

Fonty, G., GouET, PH. \& SANTE, V. (1988). Influence d'une bactérie méthanogène sur l'activité et le métabolisme de deux espèces de champignons cellulolytiques du rumen, in vitro. Résultats préliminaires. Reproduction Nutrition Developpement 28, 133-134.

GAUDET, G. (1983). Les cellulases extracellulaires de Bacteroides succinogenes. Annales de Microbiologie 134 (A), 111-114.

Gay, L., Hebraud, M., Girard, M. \& Févre, M. (1989). Chitin synthase activity from Neocallimastix frontalis, an anaerobic rumen fungus. Journal of General Microbiology 135, 279-283.

Gordon, G. L. R. \& Phillips, M. W. (1989). Comparative fermentation properties of anaerobic fungi from the rumen. In The Role of Protozoa and Fungi in Ruminant Digestion, pp. 127-138. Edited by J. V. Nolan, R. A. Leng \& D. I. Demeyer. Armidale: Penambul Books.

Hebraud, M. \& FÉVre, M. (1988). Characterization of glycosides and polysaccharide hydrolases secreted by the rumen anaerobic fungi Neocallimastix frontalis, Piromonas communis and Sphaeromonas communis. Journal of General Microbiology 134, 1123-1129.

HuNGATE, R. E. (1969). A roll tube method for the cultivation of strict anaerobes. Methods in Microbiology 3B, 117-132.

Joblin, K. N., NaYlor, G. E. \& Williams, A. G. (1990). Effect of Methanobrevibacter smithii on xylanolytic activity of anaerobic ruminal fungi. Applied and Environmental Microbiology 56, $2287-2295$.

Joblin, K. N. \& Williams, A. G. (1991). Effect of cocultivation of ruminal chytrid fungi with Methanobrevibacter smithii on lucerne stem degradation and extracellular fungal enzyme activities. Letters in Applied Microbiology 12, 121-124.

LAEMMLI, U. K. (1970). Cleavage of structural proteins during the assembly of the head of bacteriophage T4. Nature, London 227, 680-685.

Lowe, S. E., Theodorou, M. K., Trinci, A. P. J. \& Hespell, R. B. (1985). Growth of anaerobic rumen fungi on defined and semidefined media lacking rumen fluid. Journal of General Microbiology 131, 2225-2229. 
Marvin-Sikkema, F. D., Richardson, A. J., Stewart, C. S., GotTShal, J. C. \& PRINS, R. A. (1990). Influence of hydrogenconsuming bacteria on cellulose degradation by anaerobic fungi. Applied and Environmental Microbiology 56, 3793-3797.

MOUNTFORT, D. O., Asher, R. A. \& BAUCHOP, T. (1982). Fermentation of cellulose to methane and carbon dioxide by a rumen anaerobic fungus in a triculture with Methanobrevibacter sp. strain RA1 and Methanosarcina barkeri. Applied and Environmental Microbiology 44, $128-134$.

OAKLEY, B. R., KIRSH, D. R. \& MoRRIS, N. R. (1980). A simplified ultrasensitive silver stain for detecting proteins in polyacrylamide gels. Analytical Biochemistry 105, 361-363.
OrPIN, C. G. (1975). Studies on the rumen flagellate Neocallimastix frontalis. Journal of General Microbiology 91, 249-262.

SCHWARZ, W. H., BronNenmeier, K., Gräbnitz, F. \& STaudenbauer, W. L. (1987). Activity staining of cellulases in polyacrylamide gels containing mixed linkage $\beta$-glucans. Analytical Biochemistry 164, 72-77.

Stewart, C. G. \& Bryant, M. P. (1988). The rumen bacteria. In The Rumen Microbial Ecosystem, pp. 77-129. Edited by P. N. Hobson. Amsterdam: Elsevier.

WOLIN, M. J. \& Miller, T. L. (1988). Microbe-microbe interactions. In The Rumen Microbial Ecosystem, pp. 361-386. Edited by P. N. Hobson. Amsterdam: Elsevier. 